\title{
Higher Education Quality and Student Satisfaction Nexus: Evidence from Zambia
}

\author{
Bruce Mwiya, Justice Bwalya, Beenzu Siachinji, Shem Sikombe, Hillary Chanda, Moffat Chawala \\ School of Business, Copperbelt University, Kitwe, Zambia \\ Email: mwiyab@gmail.com, bruce.mwiya@cbu.ac.zm
}

How to cite this paper: Mwiya, B., Bwalya, J., Siachinji, B., Sikombe, S., Chanda, H., \& Chawala, M. (2017). Higher Education Quality and Student Satisfaction Nexus: Evidence from Zambia. Creative Education, 8, 1044-1068.

https://doi.org/10.4236/ce.2017.87076

Received: April 14, 2017

Accepted: June 5, 2017

Published: June 8, 2017

Copyright $\odot 2017$ by authors and Scientific Research Publishing Inc. This work is licensed under the Creative Commons Attribution International License (CC BY 4.0).

http://creativecommons.org/licenses/by/4.0/

\begin{abstract}
This paper contributes to the service quality literature by applying the service performance (SERVPERF) model in an under-researched Zambian universities context. Therefore, it examines the influence of each service quality dimension on overall service satisfaction and behavioural intentions in terms of loyalty and positive word of mouth. Based on a quantitative correlational design, primary data were collected from 656 senior final year undergraduate students at one public university. The findings indicate that service quality performance dimensions (tangibility, reliability, responsiveness, empathy and assurance) are each significantly positively related to overall customer satisfaction which in turn affects behavioural intentions. For scholars, administrations and policy makers, the study shows that the service performance model is a valid and useful framework for assessing and monitoring how students form their service quality perceptions and behavioural intentions. This paper is the first to extend the service performance model of service quality into the under researched developing country context of higher education in Zambia.
\end{abstract}

\section{Keywords}

Service Quality, University, Customer Satisfaction, Zambia

\section{Introduction}

In the 21st century, the purpose of universities is threefold: Knowledge creation, utilising and sharing (van Schalkwyk \& Steenkamp, 2014; Umashankar \& Dutta, 2007). In education, students are customers who come in contact with universities at a fee for the purpose of acquiring knowledge and skills (Abili, Thani, Mokhtarian, \& Rashidi, 2011; Doherty, 2008). All this is undertaken in order to equip, enrich and extend human understanding for social and economic development. Therefore, to enhance national competitiveness, university education should be the leading system for preparing and equipping the workers to be- 
come highly skilled, creative, innovative and professional. Therefore, an evaluation of education service quality becomes important.

The higher education sector in Zambia is divided into two subsectors: the universities subsector and the subsector in relation to colleges and trade institutes. The Higher Education Authority (HEA) is a government institution established under an Act of parliament No. 4 of 2013. The purpose of the HEA is to register and regulate universities in order to ensure quality of delivery of services. The HEA is expected to provide this oversight by offering quality assurance, regulatory and advisory services. However, besides registering new universities, the HEA is yet to begin executing the other responsibilities related to service quality. Since political independence from the British in 1964 to the year 2000, the country only had 2 public universities. However, from the year 2000 to 2017, the number of public universities has increased to 6 while the number of private universities has grown from 0 to 55 (Higher Education Authority, 2017). This entails that competition in the subsector has grown but mechanisms to assess and monitor service quality are yet to be devised let alone implemented. This necessitates baseline studies on the quality of higher education services from the perspectives of various stakeholders.

Universities require information and feedback on the quality of academic and administrative services they provide. This would enable them to set priorities for resource allocation, strengthen competitive capabilities for marketing and promotion purposes and seek differentiation from competitors (Cardona \& Bravo, 2012; Lam, Fong, Lauder, \& Lam, 2002). The quality of university education is fundamental to a country's development because university prepares the professionals who should be effective and efficient managers as well as technocrats in private and public firms to meet the various current and future needs of society (Pereira, Oliveira, Tinoca, Amante et al., 2009). Thus, universities need to keep in perspective the ultimate needs and interests of students, employers, alumni, parents, sponsors and government, inter alia (Rózsa, 2013). Students are considered to be the most important stakeholder of educational quality. This is because it affects them directly both in the short and long term. In fact, scholars indicate that satisfaction of other stakeholders such as parents, employers, sponsors and regulators is dependent on the satisfaction of students (Ahmed, Nawaz, Ahmad et al., 2010).

Globally, there is a small but growing body of literature on service quality in higher education. Prior studies exploring service quality in higher education in Colombia (Cardona \& Bravo, 2012), Jordan (Twaissi \& Al-Kilani, 2015), Petruzzellis, D’Uggento \& Romanazzi (2006) in Italy and Portugal (Brochado, 2009), suggest that customer satisfaction can be explained by perceived service quality. However, besides Helgesen and Nesset (2007) in Norway as well as Brown \& Mazzarol (2009) in Australia and Ali et al. (2016) in Malaysia who explore the link between student satisfaction and loyalty, there is a shortage of studies linking service quality, student satisfaction and behavioural intentions of loyalty and positive word of mouth. The implication is that, to maintain relevance and as- 
sure their own survival, universities, whether in developed or developing countries, should deliberately put in place mechanisms to assess, monitor and improve appropriate elements of service quality. Unfortunately, African countries are under-researched in terms of university service quality and this limits generalisability of prior research conclusions. In fact, literature with a Zambian context is non-existent. Reproducibility and replicability are at the heart of science and critical to the development of knowledge in any scientific field (Evanschitzky et al., 2007). The Academy of Management Journal (AMJ), globally the top most journal in business and management research, indicates that replication research is important for enhanced confidence in existing knowledge even for seemingly well understood relationships. This is especially so if a) internal or external validity issues are not yet settled for whatever reasons (e.g. limited contexts of prior research) and b) there is an empirically established relationship that should serve as a basis for broad theorising in a field or that has company-wide or public policy implications (Eden, 2002; Miller \& Bamberger, 2016: p. 314).

Zambia is a lower middle-income country with per capital income at US\$, 1490 (World Bank, 2017). The country has a collectivist culture where people regard themselves as "we" rather than "I", thus individuals feel responsible for the well-being of others including the organisations they belong to or study in (Mwiya, 2014; Hofstede, 2017). In addition, culturally, Zambia has high power distance and low masculinity scores (Hofstede, 2017) and so individuals are expected not only to respect and not question authority but also to be seen to be supportive of others. This may have an influence on how individuals evaluate service quality elements. Therefore, it would be insightful for scholars, practitioners and policy to explore if prior research findings can hold in such a different context.

The consequences of lack of research in the Zambian context are that stakeholders have no context specific evidence of the applicability of frameworks in extant literature to assess quality, develop strategies and set resource allocation priorities to improve quality. The lack of context specific research evidence entails that universities have inadequate information on their capabilities and areas requiring improvement in order to meet/exceed the expectations of stakeholders. Moreover, while the three public and prominent universities still have larger market share, competition is increasing due to a proliferation of private and public universities in Zambia from 2 in 1990 to 61 in 2016 (Ministry of Education Report, 2016; Higher Education Authority, 2017).

Therefore, the aim of this study is to assess the applicability of the service quality model (SERVPERF) in the under-researched Zambian universities context and to examine the effect of perceived service quality on student satisfaction and behavioural intentions. The rest of the paper is structured as follows: firstly, extant literature is reviewed and hypotheses developed; secondly, the methods and measurement model are described before reporting and discussing the findings of the study. Lastly, conclusions, limitations and directions for future research are highlighted. 


\section{Literature Review and Hypotheses}

\subsection{Service Quality and Customer Satisfaction in Higher Education}

\section{The Concept of Quality in Higher Education}

The concept of quality applied to goods is not extendable to the services sector (Parasuraman, Zeithaml, \& Berry, 1985). This is because while goods have physical cues for inferring quality, quality in services is underpinned by "experience" and "credence" factors. In addition, because services are performance-oriented, intangible, heterogeneous and inseparable, it is challenging to measure quality (Abili, Thani, \& Afarinandehbin, 2012). Furthermore, it is also not easy to provide the same quality to all customers all the time. Scholars indicate that service quality is the single most essential competence for survival, sustainability and growth, even for higher education institutions (van Schalkwyk \& Steenkamp, 2014). Scholars also indicate that it is becoming more difficult to attract students, since the new generation of students has more influence, greater awareness as consumers, becoming more interactive and selective about the future (Zafiropoulos \& Vrana, 2008).

Generally, service quality is the overall assessment of a service by either a customer or any other stakeholder; does the service meet/exceed expectations i.e. is it fit for purpose (Eshghi, Roy, \& Ganguli, 2008). It is a judgement or attitude relating to the overall excellence or superiority of a service (Khodayari \& Khodayari, 2011). Simply put, perceived service quality is an overall evaluation of the goodness or badness of a service (Twaissi \& Al-Kilani, 2015). Providing high service quality helps not only to retain the existing customers but also to attract new ones as a consequence of positive recommendations to other stakeholders e.g. prospective students, employers, guardians, sponsors and regulators (Ladhari, 2009; Negi, 2009). This entails that universities operating in a competitive environment have to consider how to deliver high quality service to meet the needs of stakeholders (DeShields Jr., Kara, \& Kaynak, 2005). Institution-wide student feedback about the quality of their total educational experience is an area of growing activity in universities globally (Cardona \& Bravo, 2012; Zineldin, 2007).

\section{Service Quality Frameworks in Higher Education}

Generally, there is a preponderance of literature on service quality in relation to different service industries and sectors. Regarding the proper definition of service quality and how it should be measured, there has been debate among researchers. For instance, research shows that there is no consensus on the definition of "service quality" in higher education institutions which by extension has raised controversy in measurement methodologies (Doherty, 2008; Brochado, 2009). Therefore, a number of service quality frameworks are being employed to assess service quality.

To assess service quality in universities, some studies have used SERVQUAL (Service Quality) model developed by Parasuraman et al. (1988). According to the authors, service quality can be measured by focusing on five key dimensions namely, reliability, assurance, tangibility, empathy and responsiveness (Parasu- 
raman, Zeithaml, \& Berry, 1988). Service quality level is thus determined by comparing customer perceptions with expectations. While customer perceptions are subjective evaluations of actual service experience, expectations are reference points against which actual service is judged (Brochado, 2009; Zeithaml, Bitner, \& Gremler, 2006). Despite its popular application, the SERVQUAL has been criticised by some scholars for its shortcomings at both conceptual and operational levels (Buttle, 1996). To overcome the shortcomings, the SERVPERF (Service Performance) model was developed. SERVPERF is a variant of the SERVQUAL model that adopts a performance based approach to measuring service quality by focusing only on the perceptions component (Brochado, 2009; Cronin Jr. \& Taylor, 1994).

More recently, some other frameworks have been proposed in a quest to improve accuracy in assessing university service quality. Icli and Anil (2014) proposed a new scale, called HEDQUAL, for measuring service quality in higher education institutions. This model has only been assessed in Master of Business Administration (MBA) programmes. The scale focuses on five key dimensions namely, academic quality, administrative service quality, library service quality, quality of providing career opportunities and supporting services (Icli \& Anil, 2014). Other studies have employed the HEdPERF model which is a 41 -item scale focusing not only on academic aspects but also the service environment (Abdullah, 2006; Brochado, 2009; Ali et al., 2016). The authors conceptualise academic quality as comprising five dimensions namely, non-academic aspects, academic aspects, reputation of learning institution, access and programme issues.

Last but not least, Zineldin (2007) proposed a framework, called 5Q. This comprises five key dimensions namely, quality of object, quality of process, quality of infrastructure, quality of interaction and communication, as well as quality of atmosphere (Zineldin, 2007; Zineldin, Akdag, \& Vasicheva, 2011). According to the author, quality of object implies the education services or the reason students are studying while quality of process refers to how the object is delivered. Whereas quality of infrastructure focuses on the basic resources needed to deliver educational services, the quality of interaction and communication measures the relationships between the institution and the students as well as how these are managed. Lastly, quality of atmosphere refers to trust, security and competitive positioning reflecting the institution.

Despite the lack of consensus in measurement methodologies for service quality in higher education, the SERVQUAL framework has been widely recognised and applied to assess quality from the students' perspective (Abili, Thani, \& Afarinandehbin, 2012; Saadati, 2012; Seymour, 1992; Twaissi \& Al-Kilani, 2015). However, comparing the two most popular models, i.e. SERVQUAL and SERVPERF, research has empirically tested and proven the latter to be a better measure of service quality (Adil, Akhtar, \& Khan, 2013; Brochado, 2009; Cronin Jr. \& Taylor, 1992; Dabholkar, Shepherd, \& Thorpe, 2000). In addition, Dabholkar et al. (2000) posit that the SERVPERF model is appropriate if the objective is to determine causal relationships for service quality dimensions. Based on these 
reasons, the present research employed the SERVPERF model to assess quality in higher education.

\section{Customer Satisfaction in Higher Education}

Customer satisfaction has been defined as the experience that a customer has with a service encounter in reference to what was expected (Oliver, 1980; Zeithaml, Bitner, \& Gremler, 2009; Zeithaml et al., 2006). It is outcome related whereby the customer com-pares what they had before and after experiencing a product or service (Aydin, Ozer, \& Rasil, 2005; Oliver, 1999). In simple terms, it is the feeling associated with the out-come that is equal or beyond what was expected. Satisfaction is thus based on the ability of a service provider to meet or surpass the expectations of a customer (Khan \& Matlay, 2009; Rezaei, Rezaei, Alipour, \& Salehi, 2011). Marketing literature indicates that satisfaction operates at two levels namely; transaction-specific and overall i.e. general (Yi, 1991). Transaction specific satisfaction is related to each and every encounter with a product while Overall satisfaction is the cumulative sum of all the previous satisfactions (Johnson \& Fornell, 1991; Jones \& Suh, 2000; Rezaei et al., 2011).

With respect to higher education, García-Aracil (2009) argue that there is no gener-ally accepted definition of customer satisfaction (García-Aracil, 2009). Nevertheless, there seems to be a consensus as regards conceptualising the student as the main customer of higher education institutions towards whom service performances are centred (Senthilkumar \& Arulraj, 2011; Yunus, Ishak, \& Razak, 2010). Indeed, this why in reference to universities some studies employ the phrase "student satisfaction" as opposed to "customer satisfaction" (Cardona \& Bravo, 2012; Farahmandian, Minavand, \& Afshardost, 2013; de Jager \& Gbadamosi, 2013; Sumaedi, Bakti, \& Metasari, 2011; Yunus et al., 2010). Stu-dents' satisfaction reflects outcome related experiences with university services in comparison to pre-consumption expectations. Likewise, the totality of satisfactions with specific service encounters leads to overall students' satisfaction. Student satisfaction is deemed as an important construct for understanding behavioural intentions or outcomes at the individual student level. It is also essential for considering strategies that may be used to attract and retain students for future programmes at an organisational level (Negricea, Edu, \& Avram, 2014).

In relation to measurement approaches, customer satisfaction models have focused on the service quality gap (Parasuraman, Zeithaml, \& Berry, 1994) which com-pares expectations to actual service delivered (Oliver, 1980; Rezaei et al., 2011). On the other hand, some studies have used use a single item measure to assess overall customer satisfaction (Aydin et al., 2005; Caruana, Money, \& Berthon, 2000; Ismail, Harson, Ibrahim, \& Isa, 2006; de Jager \& Gbadamosi, 2010; Theodorakis, Kambitsis, \& Laios, 2001). In this study, student satisfaction is evaluated using a single item measure to capture overall satisfaction of students.

\subsection{Service Quality, Customer Satisfaction and Behavioural Outcomes}

Extant literature indicates that quality of a service is an antecedent to overall sa- 
tisfaction for students (Arambewela \& Hall, 2006; Cardona \& Bravo, 2012; Naik, Gantasala, \& Prabhakar, 2010; Parasuraman et al., 1994; Zineldin, 2007). de Jager and Gbadamosi (2010) posit that quality of service affects students' overall experience and success of programmes as it ensures continued students' patronage. A recent study by Jiewanto et al. (2012) also concluded that service quality has a positive impact on student satisfaction. Further, previous research shows that there is a relationship between service quality dimensions and behavioural outcomes. For instance, in Jordan, Twaissi and Al-Kilani (2015) studied the impact of perceived service quality on students' behavioural intentions and found that the perceived reliability, tangibility and assurance dimensions had an effect on the students' intentions to recommend their university to others.

Undeniably, the studies above have provided insights on how service quality has been assessed along with satisfaction in higher education institutions. These insights are very critical for all higher education institutions especially in the under researched Zambian context. It can be further noted that, irrespective of the service quality framework employed, most studies conclude that there is a relationship between service quality and student satisfaction with their institution. For this reason, the current study proposes that service quality will have an effect on students' satisfaction. Accordingly, in Figure 1, Ser-vice quality dimensions (responsiveness, empathy, assurance, reliability and tangibility) are conceptualised as independent variables and student satisfaction as a dependent variable.

\section{Responsiveness and Students' Satisfaction}

According to Parasuraman et al. (1988) responsiveness refers to the "willingness to help customers and provide prompt service" (p. 23). This implies the customer will judge the performance of an organisation by the speed with which their requests, queries, or complaints are handled (Zeithaml et al., 2006). Therefore, employee actions and attitude toward service performance play a key role in customers' perceptions of a service.

With regard to higher education institutions, this implies students' perceptions of ser-vice will be affected by the University personnel's willingness to assist students, ability to communicate when service will be delivered and the speed with which the service is pro-vided. Based on empirical research, scho-

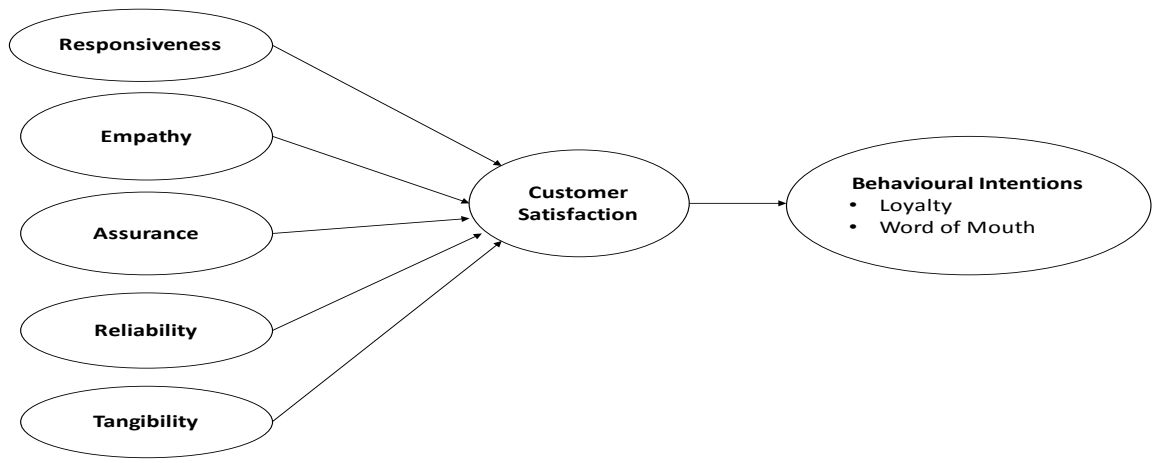

Figure 1. Conceptual model-service quality dimensions and their consequences. 
lars in Australia (Arambewela \& Hall, 2006), Pakistan (Kundi, Khan, Qureshi, Khan, \& Akhar, 2014), Malaysia (Wei \& Ramalu, 2011) and Indonesia (Jiewanto, Laurens, \& Nelloh, 2012) establish that responsiveness has an impact on students' satisfaction. That is, students that perceive a University as responsive will be more satisfied than those that do not. Therefore, this study posits as follows:

$H_{1}$ : responsiveness positively influences student satisfaction with education services

\section{Empathy and Students' Satisfaction}

Parasuraman et al. (1988) explain empathy as "caring, individualised attention given to customers" (p. 23). Typically, the individual customer forms perceptions of actual service based on how the treatment they get makes them feel special, unique and that their needs are understood (Zeithaml et al., 2006). In other words, empathy relates to the interactional quality (Pollack, 2008). In relation to higher education, empathy reflects such things as giving individualised attention and understanding the needs of students by all university staff that interact with students. Empirical research in Malaysia (Wei \& Ramalu, 2011), Iran (Rezaei et al., 2011) and in Pakistan (Kundi et al., 2014) concluded that empathy has an influence on students' satisfaction. Thus, the higher the perceived empathy, the more satisfied the student will be and vice versa. Consequently, this study postulates as follows:

$\mathrm{H}_{2}$ : empathy has a positive relationship with student satisfaction with education services

\section{Assurance and Students' Satisfaction}

Parasuraman et al. (1988) refer to assurance as "employees' knowledge and courtesy and their ability to inspire trust and confidence" (p. 23). According to Pollack (2008), assurance is also concerned with the quality of interaction. Ideally, this refers to the extent to which an individual feels the organisation instils trust and confidence (Zeithaml et al., 2006). As regards higher education institutions, assurance implies that students judge service performance based on the politeness, courteousness, friendliness and ability of university staff to explain clearly the aspects of a service. Empirically prior research in Columbia (Cardona \& Bravo, 2012), Indonesia (Jiewanto et al., 2012; Sumaedi et al., 2011) and Malaysia (Farahmandian, Minavand, \& Afshardost, 2013; Yunus et al., 2010) establish that there is positive relationship between assurance and students' satisfaction. There-fore, this study hypothesises as follows:

$\mathrm{H}_{3}$ : assurance has a positive effect on student satisfaction with education services

\section{Reliability and Students' Satisfaction}

Parasuraman et al. (1988) conceptualise reliability as the "ability to perform the promised service dependably and accurately" (p. 23). This generally entails that the firm delivers on its promises regarding outcome and core service attributes (Zeithaml et al., 2006). For the customer, what is important is not only what the firm promises but whether or not it actually delivers on those promises. Little wonder, Pollack (2008) relates reliability to outcome quality. In terms of 
higher education institutions, reliability reflects the university's ability to provide the service at the promised times, keeping students' records (academic reports, students' results, etc.) and performing error-free services. Empirically studies in Romania (Negricea et al., 2014), Australia (Sultan \& Wong, 2012) and Malaysia (Hasan, Ilias, Rahman, \& Razak, 2009; Hassan \& Ibrahim, 2010) concluded that reliability has an influence on students' satisfaction. Thus, students are more satisfied if the perceived reliability quality is high. Therefore, the study proposes that:

$H_{4}$ : reliability positively influences students' satisfaction with education services

\section{Tangibility and Students' Satisfaction}

Parasuraman et al. (1988) define tangibles as the "appearance of physical facilities, equipment, personnel, and written materials" (p. 23). Tangibility in other words relates to the physical environment quality (Pollack, 2008). Since services are intangible by nature, tangible elements enable individuals to form perceptions of service based on what they see. In higher education institutions, the tangibility aspects refer to the things that students see to judge a service. These visible things include equipment (e.g. computers, projectors, etc.), physical facilities (buildings, furniture, and classroom environment), printed university material and the university personnel's appearance. Empirical studies in Malaysia (Farahmandian, Minavand, \& Afshardost, 2013; Rajab, Rahman, \& Shaari, 2011), Pakistan (Kundi et al., 2014), Jordan (Twaissi \& Al-Kilani, 2015), establish that tangibility has an influence on student satisfaction. Likewise, the higher the perceived tangibility, the more satisfied the student will be. In line with this, the study suggests that:

$H_{5}$ : tangibility positively influences students' satisfaction with education services

\section{Student Satisfaction and Behavioural Intentions}

Scholars in marketing indicate that there is a link between customer satisfaction and customer loyalty (Walsh et al., 2009). This is because a firm that consistently provides good quality products helps to reduce perceived risks in the minds of the customers and therefore reduces the need for customers to search for alternative service provides. This reduces transaction costs. Walsh et al. (2009: p. 193) adduces evidence, based on a German energy company customers, that this would result in customer loyalty reflected in repeat business. In addition, other scholars (Sundaram, Mitra, \& Webster, 1998: p. 3) in the USA adduce evidence form customers of automobile and electronic products that, based on experience with the physical goods of the firm, consumers engage in positive word of mouth for various reasons including helping the receiving of the information; helping the entity that provides high quality products and positive service experience; and penalising the firm that does not give a positive service experience. This study extends these concepts of loyalty and positive word of mouth to the university service context. When it comes to university students, it is expected that those students who express satisfaction with the service offered by their university, would also express loyalty to the university and engage in 
positive word of mouth to others about the university. Practically, this entails that loyalty will be reflected in the intention to pursue further studies with the same university and positive word of mouth would be reflected in the intention to recommend the university to other people such as friends and relatives. Therefore, the study posits as follows:

\section{$H_{6}$ : Student Satisfaction is positively related to Loyalty to the University;}

$H_{7}$ : Student Satisfaction is positively associated with positive word of mouth about the university.

Based on the foregoing hypotheses, the conceptual Model in Figure 1 reflect the direction of influence in the relationships between customer student satisfaction and service quality elements of responsiveness, empathy, reliability, assurance and tangibility.

\section{Methods and Measurement}

\section{Population, sample and Data Collection}

The purpose of this study was to examine the relationship between the five dimensions of higher education service quality and customer satisfaction. As such it employed a quantitative correlational design (Creswell, 2012; Saunders et al., 2009). Prior studies exploring service quality in higher education in Colombia (Cardona \& Bravo, 2012), Jordan (Twaissi \& Al-Kilani, 2015) and Portugal (Brochado, 2009) have used a similar approach. In line with extant literature highlighting the need for universities to have on-going mechanisms to obtain institution-wide student feedback about the quality of their total educational experience (Cardona \& Bravo, 2012), this study focused on the student population of one of the oldest and largest public universities in an under-researched developing country context of Zambia.

Mindful of external validity, with a total student population of 12,000 (final year undergraduate students at 3000), the minimum required representative sample size would be 341, at confidence level of $95 \%$ and margin of error of 5\% (Saunders et al., 2009: p. 212, 585). To reduce the likelihood of low response rate 700 questionnaires were distributed; 656 were dully completed and returned to the researchers representing a $93.7 \%$ response rate. Final year students were particularly targeted because they had been at the university for more than 3 years and so they had more experience with the quality of various services. Additionally, impending graduation compels them to consider whether to start looking for employment or pursue further studies and at which university.

The study employed proportionate stratified sampling in selecting the sample elements based on different faculties. As for data collection, a survey was undertaken by using a self-administered questionnaire. With the help of faculty members, the questionnaire was distributed to students before the commencement of class and was collected at the end of the class. Before administering the questionnaire, the purpose of the study was explained to the respondents and then for those willing to participate, informed consent was signed by the participants prior to data collection. The resulting sample profile is given in Table 1 below 
Table 1. Respondents' profile.

\begin{tabular}{|c|c|c|c|c|}
\hline Variables & & Mean & Frequency & Percentage \\
\hline Age (years) & & 26.47 & & \\
\hline \multicolumn{5}{|l|}{ Gender } \\
\hline & Male & & 325 & 49.54 \\
\hline & Female & & 331 & 50.46 \\
\hline \multicolumn{5}{|l|}{ Field of Study } \\
\hline & Business & & 514 & 78.83 \\
\hline & Non-Business & & 138 & 21.17 \\
\hline
\end{tabular}

showing 656 full time final year undergraduate students, $50.46 \%$ female and 49.54\% male, $78.83 \%$ business students and the rest non-business students in natural sciences, natural resources and engineering degree programmes. The gender profile and the average age at 26.47 in the sample are typical of final year university students in Zambia (Mwiya, 2014: p. 156).

\section{Measurement Model Validity}

To assure internal validity, the questionnaire comprised 27 items adapted from prior similar studies in Portugal, South Africa, and Jordan (Cronin Jr. \& Taylor, 1994; Brochado, 2009; van Schalkwyk \& Steenkamp, 2014). The questionnaire comprised the 22 items on the five dimensions of higher education service quality. Additionally, there was 1 item on overall customer satisfaction ("Iam satisfied with overall educational experience at this university"). Further, 2 items were included to assess the behavioural intentions of loyalty ("I intend to later come back and pursue my postgraduate studies at this University', and "After I graduate, I Intend to participate and financially contribute to the Alumni initiatives to help my University"). Lastly, 2 items were included regarding the likelihood of spreading positive word of mouth about the institution ("I would recommend to employers to employ graduates from my University" and "Based on my experience at the University, I would recommend this University to my friends and family"). All the items were gauged on a five-point Likert scale ranging from 1 = "strongly disagree" to 5 = "strongly Agree". The questionnaire was pilot tested before mass distribution to ensure the questions were clear and where necessary correctly rephrased.

Factor analysis was performed (since sample was $>150$ ) to establish unidimensionality of constructs and validity of the independent variables (Pallant, 2016). Specifically, exploratory factor analysis with principal components extraction and Varimax rotation was conducted. The assumptions for factorability of the data (with correlation coefficients above 0.30) were fulfilled since the Kaiser-Meyer-Olkin measure of sampling adequacy was 0.945 (minimum value required 0.60), and Bartlett's Test of Sphericity was significant (Approx. Chi-square $=7130.496, \mathrm{df}=23, p=0.000)$. The cumulative percentage variance explained was $64.7 \%$. To check for consistency and stability of items, Table 2 illustrates the factor loadings resulting in clear five dimensions of service quality 
Table 2. Factor and reliability analyses for constructs.

\begin{tabular}{|c|c|c|c|c|c|}
\hline \multirow{2}{*}{ Items } & \multicolumn{5}{|c|}{ Components } \\
\hline & 1 & 2 & 3 & 4 & 5 \\
\hline Tangibility & 0.633 & & & & \\
\hline My university has up to date equipment & 0.633 & & & & \\
\hline $\begin{array}{l}\text { My university has physical facilities (e.g. buildings and furniture) } \\
\text { that are attractive, visually appealing and stylish }\end{array}$ & 0.557 & & & & \\
\hline Personnel at my university are well dressed and neat at all times & 0.773 & & & & \\
\hline $\begin{array}{l}\text { The materials at my University (e.g. pamphlets and study material) } \\
\text { suit the image of the university }\end{array}$ & 0.654 & & & & \\
\hline \multicolumn{6}{|l|}{ Reliability } \\
\hline when my university promises to do something by a certain time, it does so & & 0.688 & & & \\
\hline $\begin{array}{l}\text { When the students have problems, the personnel of } \\
\text { my university are sympathetic and reassuring }\end{array}$ & & 0.741 & & & \\
\hline My University is dependent and provides the service correctly the first time & & 0.696 & & & \\
\hline My University provides services at the time promises it promises to do so & & 0.709 & & & \\
\hline $\begin{array}{l}\text { My University keeps its records accurately } \\
\text { (e.g. accounts, academia reports, Student`s results etc.) }\end{array}$ & & 0.712 & & & \\
\hline \multicolumn{6}{|l|}{ Responsiveness } \\
\hline My University tells students when services will be rendered & & & 0.694 & & \\
\hline Students receive fast (prompt) service delivery from the University personnel & & & 0.753 & & \\
\hline Lecturers at my University are willing to assist students & & & 0.765 & & \\
\hline Personnel of the University are not too busy to respond to students' requests promptly & & & 0.674 & & \\
\hline \multicolumn{6}{|l|}{ Assurance } \\
\hline Students are able to trust the personnel of the University & & & & 0.523 & \\
\hline Personnel at my University inspire confidence & & & & 0.538 & \\
\hline Personnel at my University are polite & & & & 0.640 & \\
\hline $\begin{array}{l}\text { Personnel receive adequate support from my } \\
\text { University management to improve the performance of its services }\end{array}$ & & & & 0.745 & \\
\hline \multicolumn{6}{|l|}{ Empathy } \\
\hline $\begin{array}{l}\text { Students receive individualized attention from administrative personnel } \\
\text { (e.g. doing something extra for students). }\end{array}$ & & & & & 0.780 \\
\hline Lecturers give students individual attention & & & & & 0.674 \\
\hline $\begin{array}{l}\text { Personnel at my University know what the needs of their students are } \\
\text { (e.g. recognizing students as clients) }\end{array}$ & & & & & 0.649 \\
\hline The University personnel have the students' best interest at heart. & & & & & 0.672 \\
\hline $\begin{array}{l}\text { The University personnel are easily accessible to students } \\
\text { (e.g. available to see or to contact by phone, email etc.) }\end{array}$ & & & & & 0.714 \\
\hline Eigen Value & 9.621 & 1.729 & 1.105 & 1.003 & 1.001 \\
\hline Variance Explained (64.680\%) & 21.897 & 17.247 & 9.154 & 8.619 & 7.772 \\
\hline Cronbach Alpha & 0.763 & 0.852 & 0.708 & 0.830 & 0.869 \\
\hline
\end{tabular}


with Eigen values above 1. All Cronbach's Alpha values were above the minimum threshold of 0.70 (Pallant, 2016).

Prior to further bivariate and multivariate analyses, checks for missing data, outliers and normality were conducted on the scale data. Descriptive statistics revealed that missing data for the variables and respondents ranged between $1.2 \%$ and $3.3 \%$. Missing data under $10 \%$ for each respondent or variable can generally be ignored because it does not have a significant adverse effect on any analyses. With regard to outliers, inspection of boxplots and comparison of actual means with the $5 \%$ trimmed means for the variables revealed no extreme scores with strong influence on the means (Pallant, 2016). In relation to normality for all variables, kurtosis and skewness were within the acceptable \pm 1 range for psychometric tests (George \& Mallery, 2003).

\section{Results}

\section{Correlation analyses}

Pearson correlation analysis was performed to assess the direction and strengthen of relationships among all variables. Table 3 presents the correlations, means and standard deviations of the dependent variables (overall customer satisfaction, positive word of mouth and loyalty), independent variables (perceived responsiveness, perceived empathy, perceived assurance, perceived reliability, perceived tangibility) and control variables (actual age and gender). The results in Table 3 show relatively low correlations among variables (all of them below 0.8 ). This entails that multicollinearity is not a problem (Tabachnik, Fidell, \& Tabachnick, 2007). Firstly, for the control variables, though both age and gender are positively correlated with customer satisfaction only age is significant. This means that older individuals are more likely to report satisfaction. Among several explanations, this could be because older individuals are less over-particular about their choices; probably because they understand the cons-

Table 3. Mean, Standard Deviation (SD) and correlation matrix.

\begin{tabular}{|c|c|c|c|c|c|c|c|c|c|c|c|c|c|}
\hline & Variable & Mean & SD & $\mathrm{N}$ & 1 & 2 & 3 & 4 & 5 & 6 & 7 & 8 & 9 \\
\hline 1 & Customer Satisfaction & 3.239 & 1.048 & 641 & & & & & & & & & \\
\hline 2 & Loyalty & 3.201 & 0.934 & 645 & $0.438^{\star *}$ & & & & & & & & \\
\hline 3 & Positive Word of Mouth & 3.843 & 0.919 & 639 & $0.563^{\star *}$ & $0.546^{\star *}$ & & & & & & & \\
\hline 4 & Actual age & 26.470 & 5.765 & 656 & $0.141^{\star *}$ & $0.214^{* *}$ & $0.125^{\star *}$ & & & & & & \\
\hline 5 & Gender & 0.500 & 0.500 & 653 & 0.025 & -0.029 & -0.030 & 0.073 & & & & & \\
\hline 6 & Perceived Responsiveness & 3.014 & 0.791 & 653 & $0.291^{\star *}$ & $0.297^{\star *}$ & $0.241^{* *}$ & $0.246^{* *}$ & 0.014 & & & & \\
\hline 7 & Perceived Empathy & 2.831 & 0.929 & 653 & $0.299^{\star *}$ & $0.295^{\star *}$ & $0.296^{\star *}$ & $0.278^{\star *}$ & -0.067 & $0.635^{\star *}$ & & & \\
\hline 8 & Perceived Assurance & 2.866 & 0.898 & 653 & $0.308^{* *}$ & $0.304^{* *}$ & $0.278^{\star *}$ & $0.275^{\star *}$ & -0.067 & $0.679^{* *}$ & $0.744^{* *}$ & & \\
\hline 9 & Perceived Reliability & 2.691 & 0.886 & 653 & $0.328^{* *}$ & $0.336^{* *}$ & $0.276^{\star *}$ & $0.232^{\star *}$ & -0.031 & $0.655^{* *}$ & $0.582^{* *}$ & $0.603^{* *}$ & \\
\hline 10 & Perceived Tangibility & 2.749 & 0.789 & 653 & $0.373^{\star *}$ & $0.320^{\star *}$ & $0.290^{\star *}$ & $0.193^{\star *}$ & -0.055 & $0.548^{\star *}$ & $0.517^{\star *}$ & $0.562^{\star \star}$ & $0.674^{* *}$ \\
\hline
\end{tabular}

${ }^{*}$ Correlation is significant is significant at the 0.01 level (2-tailed). 
traints the country and the public university operates under. Another explanation is the notion that Zambia is a collectivist and feminine society with high power distance (Hofstede, 2017). Therefore, older individuals are more likely to conform to norms of society which dictate that one needs to be seen to respect authority and supportive of societal institutions. As a consequence, older individuals would be less inclined to complain about any dissatisfaction with service quality.

Secondly, Table 3 indicates that student satisfaction is positively significantly correlated (all sig. $\leq 0.01$ ) with each service quality dimension of university education i.e. tangibility $(r=0.373)$, reliability $(r=0.328)$, assurance $(0.308)$, empathy $(r=0.299)$ and perceived responsiveness $(r=0.291)$. The effect sizes are generally medium based on Cohen's criteria i.e. small $=0.10$ to 0.29 , medium .30 to 0.49 and large $=0.50$ to 1.00 (Cohen, 1988). Thirdly, the significant positive correlations indicate that the higher the level of customer satisfaction, the higher the level of loyalty $\left(r=0.438, p<0.01\right.$ with medium effect size, $\left.r^{2}=0.205\right)$ and positive word of mouth $\left(\mathrm{r}=0.563, p<0.01\right.$ with large effect size, $\left.\mathrm{r}^{2}=0.317\right)$. This supports $\mathrm{H}_{6}$ and $\mathrm{H}_{7}$, which postulate that customer satisfaction is positively related to student loyalty and positive word of mouth recommendations. This means that individuals who are satisfied with the education service at the university are more likely to encourage friends and relatives to pursue their studies at the same university and they are also more likely to encourage employers to employ graduates from that university. Similarly, students who are satisfied with the education service are more likely to intend to return to the same university to pursue further studies or support the university as part of the alumni.

\section{Hierarchical Regression analyses}

To evaluate the ability of the multiple regression model (where the service quality dimensions are the explanatory variables) to predict customer satisfaction (outcome variable), after controlling for age and gender, hierarchical regression analysis was conducted. Table 4 presents the results with overall customer satisfaction as a dependent variable. The overall customer satisfaction model hypothesises that perceived responsiveness, perceived empathy, perceived assurance, perceived reliability and perceived tangibility are the main determinants of overall customer satisfaction (Rod, Ashill, Shao, \& Carruthers, 2009). From Table 4, preliminary checks indicate that multicollinearity is not a problem because the variance inflation factor (VIF) values were lower than 5 for the independent and control variables (Koe, 2016; Pallant, 2016). Further, all regression coefficients are in the expected positive direction.

Model 1 shows the base model with control variables only i.e. actual age and gender. The control variables make a combined significant contribution of adjusted multiple coefficient of determination (R-Square) of $1.7 \%$ and multiple correlation coefficient of (R) 0.141, representing a combined small effect size. Individually, actual age is significant while gender is not. The rationale for significant influence of age on customer satisfaction may be that as students progress to higher levels of study they become experienced and mature and are 
Table 4. Hierarchical regression analyses.

\begin{tabular}{|c|c|c|c|c|c|c|c|}
\hline \multirow{2}{*}{ Variable } & \multirow{2}{*}{ Model 1} & Model 2 & Model 3 & Model 4 & Model 5 & Model 6 & VIF \\
\hline & & Beta, $t$, & Beta, $t$, & Beta, $t$, & Beta, $t$, & Beta, $t$, & VIF \\
\hline \multicolumn{8}{|l|}{ Control Variables } \\
\hline Actual age & $0.140^{* * *}, 3.495$ & $0.072,1.818$ & $0.047,1.173$ & $0.040,1.002$ & $0.034,0.845$ & $0.034,0.866$ & 1.112 \\
\hline Gender & $0.015,0.713$ & $0.016,0.411$ & $0.032,0.827$ & $0.037,0.827$ & $0.040,1.058$ & $0.046,1.241$ & 1.025 \\
\hline \multicolumn{8}{|l|}{ Independent Variables } \\
\hline Perceived Responsiveness & & $0.273^{* * *}, 6.888$ & $0.161^{\star * *}, 3.245$ & $0.115^{\star}, 2.136$ & $0.038,0.658$ & $0.019,0.338$ & 2.364 \\
\hline Perceived Empathy & & & $0.186^{\star * \star}, 3.712$ & $0.119^{*}, 2.005$ & $0.087,1.459$ & $0.074,1.234$ & 2.503 \\
\hline Perceived Assurance & & & & $0.133^{\star}, 2.137$ & $0.099,1.584$ & $0.056,0.905$ & 2.822 \\
\hline Perceived Reliability & & & & & $0.186^{* * *}, 3.543$ & $0.068,1.186$ & 2.431 \\
\hline Perceived Tangibility & & & & & & $0.243^{* * *}, 4.658$ & 1.990 \\
\hline $\mathrm{R}$ & 0.141 & 0.300 & 0.332 & 0.341 & 0.367 & 0.405 & \\
\hline R Square & 0.020 & 0.090 & 0.110 & 0.117 & 0.134 & 0.164 & \\
\hline Adjusted R Square & 0.017 & 0.086 & 0.104 & 0.109 & 0.126 & 0.154 & \\
\hline F-statistic & $6.303^{* *}$ & $20.333^{\star * *}$ & $19.01^{\star * *}$ & $16.209^{* * *}$ & $15.855^{\star * *}$ & $17.148^{\star * *}$ & \\
\hline
\end{tabular}

${ }^{* * *} \operatorname{sig}<0.001(0.1$ percent $) ;{ }^{* *} \operatorname{sig}<0.01(1$ percent $) ;{ }^{*}$ sig $<0.05$ (5 percent); VIF = Variance Inflation factor.

able to appreciate the significance of the university compared to other universities in the country. It is also possible that older students are less over-particular in their preferences.

In model 2, in addition to control variables, perceived responsiveness is introduced and a significant combined effect occurs (adjusted $\mathrm{R}^{2}=8.6 \%$ from $1.7 \%$ ), with $\mathrm{R}=0.300$ representing a combined medium effect size. Individually, only perceived responsiveness makes a significant contribution. For responsiveness, this means that the higher the level of perception among customers (students) that university personnel are willing and actually providing prompt service and helping them to achieve their goals, the higher the levels of customer satisfaction. Therefore, $\mathrm{H}_{1}$, which postulates that responsiveness positively influences students' satisfaction with the education service at university, has been supported.

In model 3, in addition to control variables and perceived responsiveness, perceived empathy is introduced and a significant combined effect occurs (adjusted $\mathrm{R}^{2}$ of $10.4 \%$ from $8.6 \%$ ), with $\mathrm{R}=0.332$ representing a combined medium effect size. Individually, only perceived responsiveness and perceived empathy make a significant contribution. For empathy, this means that as customers (students) perceive that university personnel are willing to take care of the customers by providing individualistic attention and rendering ears to their problems and effectively addressing their concerns and demands (Blery et al., 2009), their levels of satisfaction with the service will be higher. Therefore, $\mathrm{H}_{2}$, which postulates that perceived empathy positively influences students' satisfaction with the education services from the university, has been supported. 
In model 4, in addition to control variables, perceived responsiveness, and empathy, another variable i.e. perceived assurance is introduced and a significant combined effect occurs (adjusted $\mathrm{R}^{2}=10.9 \%$ from $10.4 \%$ ), with $\mathrm{R}=0.341$ representing a combined medium effect size. Individually, perceived responsiveness, empathy and assurance make a significant contribution. This means that customers (students) who perceive that university personnel possess knowledge and relevant ability and therefore inspire trust and confidence in providing the promised services to customers (Blery et al., 2009) are more likely to report higher satisfaction with the service. Therefore, $\mathrm{H}_{3}$, which postulates that perceived assurance positively influences students' satisfaction with the education service, has been supported.

In model 5, in addition to control variables, perceived responsiveness, empathy and assurance, another variable i.e. perceived reliability is introduced and a significant combined effect occurs (adjusted $\mathrm{R}^{2}=12.6 \%$ from $10.9 \%$ ), with $\mathrm{R}=$ 0.367 representing a combined medium effect size. Individually, only perceived reliability makes a statistically significant contribution. This means that the more customers (students) perceive university personnel as having the ability and actually fulfilling the promised service in a committed manner, truthfully and consistently (Blery et al., 2009), the more they will report customer satisfaction. Therefore, $\mathrm{H}_{4}$, which postulates that perceived reliability positively influences students' satisfaction with the education service, has been supported.

In model 6, in addition to control variables, perceived responsiveness, empathy, assurance and reliability, the last independent variable i.e. perceived tangibility is introduced. A significant combined effect occurs (adjusted R2 $=16.4 \%$ from $12.6 \%$ ), with $\mathrm{R}=0.405$ representing a combined medium effect size. Individually, only perceived tangibility makes a statistically significant contribution. This means that customers (students) appreciate the overall outlook of the university, its physical appearance as being visually appealing and stylish (Blery et al., 2009) would report higher customer satisfaction. Therefore, $H_{5}$, which postulates that perceived tangibility positively influences students' satisfaction with the education service, has been supported.

Based on the correlation matrix (Table 3 ) hierarchical regression (Table 4), Table 5 below summarises the results of hypotheses testing.

Table 5. Results of hypotheses testing.

\begin{tabular}{ccccc}
\hline$\#$ & \multicolumn{1}{c}{ Hypotheses } & Statistic & Test & Results \\
\hline H1 & Responsiveness is positively related to Student Satisfaction & $\mathrm{B}=0.273^{* * *}$ & Regression & Supported \\
H2 & Empathy is positively related to Student Satisfaction & $\mathrm{B}=0.186^{* * *}$ & Regression & Supported \\
H3 & Assurance positively influences Student Satisfaction & $\mathrm{B}=0.133^{*}$ & Regression & Supported \\
H4 & Reliability is positively associated with Student Satisfaction & $\mathrm{B}=0.186^{* * *}$ & Regression & Supported \\
H5 & Tangibility is positively correlated with Student Satisfaction & $\mathrm{B}=0.243^{* * *}$ & Regression & Supported \\
H6 & Student Satisfaction is positively associated with Loyalty & $\mathrm{R}=0.438^{* *}$ & Correlation & Supported \\
H7 & Student Satisfaction is positively associated with Word of Mouth & $\mathrm{R}=0.563^{* * *}$ & Correlation & Supported \\
\hline
\end{tabular}

${ }^{* * *}$ sig < 0.001( 0.1 percent); ${ }^{* *}$ sig < 0.01 (1 percent); ${ }^{*}$ sig < 0.05 ( 5 percent). 
Lastly, Model 6 in Table 4 also presents the multiple regression with all the control and independent variables' effects on overall customer satisfaction reflected. When all the variables are considered in totality, while all the variables make a positive contribution, only perceived tangibility remains statistically significant and has the largest contribution based on the beta values i.e. perceived tangibility: Beta $=0.243, p<0.001$, perceived reliability: Beta $=0.068, p>0.05$, perceived assurance: Beta $=0.056, p>0.05$, perceived empathy: Beta $=0.074, p>$ 0.05 , perceived responsiveness: Beta $=0.0 .019, p>0.05$.

\section{Discussion}

The findings in this study suggest that perceived responsiveness, empathy, assurance, reliability and tangibility each significantly influence overall customer satisfaction in public universities in Zambia. Based on the comprehensive multiple regression model, the largest predictor of satisfaction is perceived tangibility. However, the correlation results indicate that inter-correlations among the dimensions of service quality range between $\mathrm{R}=0.517$ to $\mathrm{R}=0.714$, representing a large size effect. This means that perceptions of good performance in one quality dimension positively influences perceptions in the other dimensions. The implication is that service quality elements should be monitored, developed and improved as a whole and not in isolation from each other.

The findings from this study have supported the conceptual model and all the hypothesised relationships. This means that the higher the level of perceived good service performance in tangibles, reliability, assurance, empathy and responsiveness to customer's needs, the higher the level of customer satisfaction. In turn, customer satisfaction positively influences customer loyalty intentions and positive word of mouth. These findings resonate with prior studies in Colombia (Cardona \& Bravo, 2012), Jordan (Twaissi \& Al-Kilani, 2015) and Portugal (Brochado, 2009) that found that customer satisfaction is significantly influenced by the five service quality dimensions. This entails that even in collectivist, lower middle income countries, service quality dimensions are valid predictors of customer satisfaction.

Further, this study is among the few to offer empirical evidence, based on the SERVPERF scale, that student satisfaction positively influences behavioural intentions of loyalty and positive word of mouth. This means that individuals who are satisfied with the education service at the university are more likely to encourage friends and relatives to pursue their studies at the same university and they are also more likely to encourage employers to employ graduates from that university. Similarly, students who are satisfied with the education service are more likely to intend to return to the same university to pursue further studies or support the university as part of the alumni.

Lastly, the finding that older individuals are more likely to report satisfaction is very interesting. Among several explanations, this could be because older individuals are less over-particular about their choices; probably because they understand the constraints the country and the public university operates under. 
Another explanation is the notion that Zambia is a collectivist and feminine society with high power distance (Hofstede, 2017). Therefore, older individuals, pressured by society to lead by example, are more likely to conform to norms of society which dictate that one needs to be seen to respect authority and supportive of societal institutions. As a consequence, older individuals would be less inclined to complain about any dissatisfaction with service quality.

\section{Conclusions, Contribution and Implications}

The purpose of this research was to apply the service performance (SERVPERF) model in a Zambian context and determine the influence of each service quality dimension on overall service satisfaction. The study was based on a quantitative correlational design where primary sample data were collected from 656 final year undergraduate students at one public university in Zambia. The main findings indicate that each of the five dimensions of service quality performance dimensions (tangibility, reliability, responsiveness, empathy and assurance) is significantly and positively related to overall customer satisfaction, which in turn is related to loyalty and positive word of mouth.

The contributions of this research are threefold. Firstly, prior studies exploring service quality in higher education in Colombia (Cardona \& Bravo, 2012), Jordan (Twaissi \& Al-Kilani, 2015), Petruzzellis, D’Uggento \& Romanazzi (2006) in Italy and Portugal (Brochado, 2009), suggest that customer satisfaction can be explained by perceived service quality. However, African countries are underresearched and this limits generalisability of research conclusions. In fact, hitherto, literature with a Zambian context is non-existent. The consequences of lack of research in the Zambian context entail that stakeholders have no basis for developing strategies and setting resource allocation priorities to improve service quality based on context specific conclusions. Therefore, this study has contributed to filling this contextual gap in knowledge, thus extending the generalisability of prior research conclusions and improving external validity (Eden, 2002; Miller \& Bamberger, 2016; Evanschitzky et al., 2007). Indeed, the study has confirmed the applicability of the SERVPERF model in a collectivist, high power distance, feminine and lower middle income country like Zambia.

Secondly, besides Helgesen and Nesset (2007) in Norway as well as Brown \& Mazzarol (2009) in Australia and Ali et al. (2016) in Malaysia who explore the link between student satisfaction and loyalty, there is a shortage of studies linking service quality, student satisfaction and behavioural intentions of loyalty and positive word of mouth. This study is among the few to offer empirical evidence, based on the SERVPERF scale that student satisfaction positively influences behavioural intentions of loyalty and positive word of mouth. Thirdly, the study contributes evidence that older individuals in a collectivist, high power distance and feminine society are more likely to report customer satisfaction. This is perhaps because they are more likely to feel pressure to conform to the norms of society and to be seen to be supportive of societal institutions. As a consequence, older individuals would be less inclined to complain about dissatisfaction with 
service quality.

Implications for scholars, administrations and policy makers are that the service performance model (SERVPERF) is a valid and useful framework for assessing and monitoring how the primary stakeholders form their service quality perceptions of higher education. Therefore, customer satisfaction is a function of perceptions of performance in the service quality dimensions of tangibility, reliability, responsiveness, assurance and empathy. The study's findings also imply that perceptions of good performance in one quality dimension positively influence perceptions in the other dimensions of quality. This means that service quality elements should be monitored, developed and improved as a whole and not in isolation from each other. This also means that the higher the level of perceived good service performance in tangibles, reliability, assurance, empathy and responsiveness to customers' needs, the higher the level of customer satisfaction. In turn, students who are satisfied with the education service are more likely to pursue further studies at the same university, support the university as alumni and engage in positive word of mouth to friends, family, employers and other stakeholders about the university.

\section{Limitations and Directions for Future Research}

Being a cross sectional study, this research could only offer a snapshot of the phenomenon. Thus, only correlation rather than causality can be inferred. In future longitudinal studies conducted annually as an all-encompassing, holistic and recognised higher education service quality evaluation system would help institutions to assess and monitor their service quality performance. Additionally, since the sample was limited to one public university, in future a sample drawn from public and private universities would improve generalizability of the conclusions. This would also help compare service quality and customer satisfaction between private and public universities.

\section{Acknowledgements}

The authors wish to thank Sandra Muzeya, Chiluba Mbulo and Nicole Mweema for data entry support.

\section{References}

Abdullah, F. (2006). Measuring Service Quality in Higher Education: HEdPERF versus SERVPERF. Marketing Intelligence \& Planning, 24, 31-47. https://doi.org/10.1108/02634500610641543

Abili, K., Thani, F. N., \& Afarinandehbin, M. (2012). Measuring University Service Quality by Means of SERVQUAL Method. Asian Journal on Quality, 13, 204-211. http://www.emeraldinsight.com/doi/abs/10.1108/15982681211287766 https://doi.org/10.1108/15982681211287766

Abili, K., Thani, F. N., Mokhtarian, F., \& Rashidi, M. M. (2011). Assessing Quality Gap of University Services. Asian Journal on Quality, 12, 167-175.

http://www.emeraldinsight.com/doi/pdf/10.1108/15982681111158724 https://doi.org/10.1108/15982681111158724 
Adil, M., Akhtar, A., \& Khan, M. (2013). Refinement of Internet Banking Service Quality Scale: A Confirmatory Factor Analysis Approach. International Journal of Services and Operations Management, 14, 336.

http://www.inderscienceonline.com/doi/abs/10.1504/IJSOM.2013.052094 https://doi.org/10.1504/ijsom.2013.052094

Ahmed, I., Nawaz, M., Ahmad, Z. et al. (2010). Does Service Quality Affect Students' Performance? Evidence from Institutes of Higher Learning. African Journal of Business Management, 4, 2527-2533.

http://search.proquest.com/openview/7d8459a7f381844dcf82762dc9413f9f/1?pq-origsit $\underline{\mathrm{e}=\text { gscholar } \& \mathrm{cbl}=816394}$

Ali, F., Zhou, Y., Hussain, K., Nair, P. K., \& Ragavan, N. A. (2016). Does Higher Education Service Quality Effect Student Satisfaction, Image and Loyalty? A Study of International Students in Malaysian Public Universities. Quality Assurance in Education, 24, 70-94. https://doi.org/10.1108/QAE-02-2014-0008

Arambewela, R., \& Hall, J. (2006). A Comparative Analysis of International Education Satisfaction Using SERVQUAL. Journal of Services Research, 6, 141-163.

Aydin, S., Ozer, G. O., \& Rasil, A. (2005). Customer Loyalty and the Effect of Switching Costs as a Moderator Variable. Marketing Intelligence and Planning, 23, 89-103. https://doi.org/10.1108/02634500510577492

Blery, E., Batistatos, N., Papastratou, E., Perifanos, I., Remoundaki, G., \& Retsina, M. (2009). Service Quality and Customer Retention in Mobile Telephony. Journal of Targeting, Measurement and Analysis for Marketing, 17, 27-37. https://doi.org/10.1057/jt.2008.26

Brochado, A. (2009). Comparing Alternative Instruments for Measuring Service Quality in Higher Education. Quality Assurance in Education, 17, 174-190. https://doi.org/10.1108/09684880910951381

Brown, R. M., \& Mazzarol, T. W. (2009). The Importance of Institutional Image to Student Satisfaction and Loyalty within Higher Education. Higher Education, 58, 81-95. https://doi.org/10.1007/s10734-008-9183-8

Buttle, F. (1996). SERVQUAL: Review, Critique, Research Agenda. European Journal of Marketing, 30, 8-32.

http://www.emeraldinsight.com/doi/abs/10.1108/03090569610105762 https://doi.org/10.1108/03090569610105762

Cardona, M., \& Bravo, J. (2012). Service Quality Perceptions in Higher Education Institutions: The Case of a Colombian University. Estudios Gerenciales, 28, 23-29. http://www.sciencedirect.com/science/article/pii/S0123592312700049 https://doi.org/10.1016/S0123-5923(12)70004-9

Caruana, A., Money, A. H., \& Berthon, P. R. (2000). Service Quality and SatisfactionThe Moderating Role of Value. European Journal of Marketing, 34, 1338-1352. https://doi.org/10.1108/03090560010764432

Cohen, J. W. (1988). Statistical Power Analysis for the Behavioral Sciences (2nd ed.). Hillsdale, NJ: Lawrence Erlbaum Associates.

Creswell, J. (2012). Educational Research: Planning, Conducting, and Evaluating Qualitative Research (4th Edition). Thousand Oaks, CA: Pearson Education.

Cronin Jr., J. J., \& Taylor, S. (1992). Measuring Service Quality: A Reexamination and Extension. The Journal of Marketing, 56, 55-68. http://www.jstor.org/stable/1252296 https://doi.org/10.2307/1252296

Cronin Jr., J., \& Taylor, S. (1994). SERVPERF versus SERVQUAL: Reconciling Performance-Based and Perceptions-Minus-Expectations Measurement of Service Quality. 
Journal of Marketing, 58, 125-131. https://doi.org/10.2307/1252256

Dabholkar, P. A., Shepherd, C. D., \& Thorpe, D. I. (2000). A Comprehensive Framework for Service Quality: An Investigation of Critical Conceptual and Measurement Issues through a Longitudinal Study. Journal of Retailing, 76, 139-173. https://doi.org/10.1016/S0022-4359(00)00029-4

de Jager, J., \& Gbadamosi, G. (2010). Specific Remedy for Specific Problem: Measuring Service Quality in South African Higher Education. Higher Education, 60, 251-267. http://link.springer.com/article/10.1007/s10734-009-9298-6 https://doi.org/10.1007/s10734-009-9298-6

de Jager, J., \& Gbadamosi, G. (2013). Predicting Students' Satisfaction through Service Quality in Higher Education. The International Journal of Management Education, 11, 107-118. http://www.sciencedirect.com/science/article/pii/S1472811713000347 https://doi.org/10.1016/j.ijme.2013.09.001

DeShields Jr., O. J., Kara, A., \& Kaynak, E. (2005). Determinants of Business Student Satisfaction and Retention in Higher Education: Applying Herzberg's Two-Factor Theory. International Journal of Educational Management, 19, 128-139.

http://www.emeraldinsight.com/doi/pdf/10.1108/09513540510582426 https://doi.org/10.1108/09513540510582426

Doherty, G. D. (2008). On Quality in Education. Quality Assurance in Education, 16, 255-265. https://doi.org/10.1108/09684880810886268

Eden, D. (2002). From the Editors. Academy of Management Journal, 45, 841-846. https://doi.org/10.5465/AMJ.2002.7718946

Eshghi, A., Roy, S., \& Ganguli, S. (2008). Service Quality and Customer Satisfaction: An Empirical Investigation in Indian Mobile Telecommunications Services. The Marketing Management Journal, 18, 119-144.

Evanschitzky, H., Baumgarth, C., Hubbard, R., \& Armstrong, J. S. (2007). Replication Research's Disturbing Trend. Journal of Business Research, 60, 411-415.

https://doi.org/10.1016/j.jbusres.2006.12.003

Farahmandian, S., Minavand, H., \& Afshardost, M. (2013). Perceived Service Quality and Student Satisfaction in Higher Education. IOSR Journal of Business and Management, 12, 65-74. https://doi.org/10.9790/487X-1246574

García-Aracil, A. (2009). European Graduates' Level of Satisfaction with Higher Education. Higher Education, 57, 1-21. https://doi.org/10.1007/s10734-008-9121-9

George, D., \& Mallery, P. (2003). Using SPSS for Windows Step by Step: A Simple Guide and Reference (4th ed.). London: Pearson Education.

Hasan, H. F. A., Ilias, A., Rahman, R. A., \& Razak, M. Z. A. (2009). Service Quality and Student Satisfaction: A Case Study at Private Higher Education Institutions. International Business Research, 1, 163-175.

http://www.ccsenet.org/journal/index.php/ibr/article/view/982 https://doi.org/10.5539/ibr.v1n3p163

Hassan, A., \& Ibrahim, M. (2010). Designing Quality e-Learning Environments for Higher Education. Educational Research, 1, 186-197.

https://www.researchgate.net/profile/Mohamed_Elhoseny4/publication/275891526_De sign-

ing_quality_e-learning_environments_for_higher_education/links/5548ef3a0cf205bce7 abfd68.pdf

Helgesen, Ø., \& Nesset, E. (2007). What Accounts for Students' Loyalty? Some Field Study Evidence. International Journal of Educational Management, 21, 126-143.

https://doi.org/10.1108/09513540710729926 
Higher Education Authority (2017). Registered Universities.

http://www.hea.org.zm/index.php/en/registered-universities

Hofstede, G. (2017). What about Zambia? On Cultural Dimensions.

https://geert-hofstede.com/zambia.html

Icli, G., \& Anil, N. (2014). The HEDQUAL Scale: A New Measurement Scale of Service Quality for MBA Programs in Higher Education. South African Journal of Business Management, 45, 31-43. https://journals.co.za/content/busman/45/3/EJC159440

Ismail, I., Harson, H., Ibrahim, N. S., \& Isa, M. (2006). Service Quality, Client Satisfaction and Loyalty Towards Audit Firms: Perceptions of Malaysian Public Listed Companies. Managerial Auditing Journal, 21, 738-756. https://doi.org/10.1108/02686900610680521

Jiewanto, A., Laurens, C., \& Nelloh, L. (2012). Influence of Service Quality, University Image, and Student Satisfaction toward WOM Intention: A Case Study on Universitas Pelita Harapan Surabaya. Procedia-Social and Behavioral Sciences, 40, 16-23. https://doi.org/10.1016/j.sbspro.2012.03.155

Johnson, M. D., \& Fornell, C. (1991). A Framework for Comparing Customer Satisfaction across Individuals and Product Categories. Journal of Economic Psychology, 12, $267-$ 286. https://doi.org/10.1016/0167-4870(91)90016-M

Jones, M. A., \& Suh, J. (2000). Transaction-Specific Satisfaction and Overall Satisfaction: An Empirical Analysis. Journal of Services Marketing, 14, 147-159. https://doi.org/10.1108/08876040010371555

Khan, H., \& Matlay, H. (2009). Implementing Service Excellence in Higher Education. Education + Training, 51, 769-780. https://doi.org/10.1108/00400910911005299

Khodayari, F., \& Khodayari, B. (2011). Service Quality in Higher Education. Interdisciplinary Journal of Research in Business, 1, 38-46.

http://higheducation.idsc.gov.eg/upload/quality\%20in\%20higher\%20education_03_01_ 2012_04_28_r.pdf

Koe, W.-L. (2016). The Relationship between Individual Entrepreneurial Orientation (IEO) and Entrepreneurial Intention. Journal of Global Entrepreneurship Research, 6, 13. https://doi.org/10.1186/s40497-016-0057-8

Kundi, G. M., Khan, S. M., Qureshi, Q. A., Khan, Y., \& Akhar, R. (2014). Impact of Service Quality on Customer Satisfaction in Higher Education. (A Case Study of Gomal University, DI Khan, Khyber Pakhtunkhwa Pakistan). Higher Education, 4, 23-28.

Ladhari, R. (2009). Service Quality, Emotional Satisfaction, and Behavioural Intentions: A Study in the Hotel Industry. Managing Service Quality: An International Journal, 19, 308-331. http://www.emeraldinsight.com/doi/abs/10.1108/09604520910955320 https://doi.org/10.1108/09604520910955320

Lam, C., Fong, D., Lauder, I., \& Lam, T. (2002). The Effect of Health-Related Quality of Life (HRQOL) on Health Service Utilisation of a Chinese Population. Social Science \& Medicine, 55, 1635-1646. https://doi.org/10.1016/S0277-9536(01)00296-9

Miller, C. C., \& Bamberger, P. (2016). Exploring Emergent and Poorly Understood Phenomena in the Strangest of Places: The Footprint of Discovery in Replications, Meta-Analyses, and Null Findings. Academy of Management Discoveries, 2, 313-319. https://doi.org/10.5465/amd.2016.0115

Ministry of Education Report (2016). List of Recognised Universities in Zambia. Lusaka. http://www.moe.gov.zm/index.php/component/content/article/54-directory/146-unive $\underline{\text { rsities }}$

Mwiya, B. M. K. (2014). The Impact of Entrepreneurship Education on the Relationships between Institutional and Individual Factors and Entrepreneurial Intention of University Graduates: Evidence from Zambia. Doctoral Dissertation. 
Naik, C. K., Gantasala, S. B., \& Prabhakar, G. V. (2010). Service Quality (SERVQUAL) and Its Effect on Customer Satisfaction in Retailing. European Journal of Social Sciences, 16, 231-243.

https://pdfs.semanticscholar.org/d124/e866687313a05a8ae38c2cd8d7f49e257830.pdf

Negi, R. (2009). Determining Customer Satisfaction through Perceived Service Quality: A Study of Ethiopian Mobile Users. International Journal of Mobile Marketing, 4, 31.

Negricea, C., Edu, T., \& Avram, M. (2014). Establishing Influence of Specific Academic Quality on Student Satisfaction. Social and Behavioral Sciences, 116, 4430-4435.

Oliver, R. (1980). A Cognitive Model of the Antecedents and Consequences of Satisfaction Decisions. Journal of Marketing Research, 17, 460-469.

http://www.jstor.org/stable/3150499

https://doi.org/10.2307/3150499

Oliver, R. L. (1999). Whence Consumer Loyalty? Journal of Marketing, 63, 33-44. https://doi.org/10.2307/1252099

Pallant, J. (2016). SPSS Survival Manual: A Step By Step Guide to Data Analysis Using SPSS Program (6th ed.). London, UK: McGraw-Hill Education.

Parasuraman, A., Zeithaml, V., \& Berry, L. (1985). A Conceptual Model of Service Quality and its Implications for Future Research. The Journal of Marketing, 49, 41-50. http://www.jstor.org/stable/1251430 https://doi.org/10.2307/1251430

Parasuraman, A., Zeithaml, V., \& Berry, L. (1988). Servqual: A Multiple-Item Scale for Measuring Consumer Perceptions of Service Quality. Journal of Retailing, 64, 12. http://search.proquest.com/openview/7d007e04d78261295e5524f15bef6837/1?pq-origsi $\underline{\text { te }=\text { gscholar } \& \mathrm{cbl}=41988}$

Parasuraman, A., Zeithaml, V., \& Berry, L. (1994). Reassessment of Expectations as a Comparison Standard in Measuring Service Quality: Implications for Further Research. The Journal of Marketing, 58, 111-124. http://www.jstor.org/stable/1252255 https://doi.org/10.2307/1252255

Pereira, A., Oliveira, I., Tinoca, L., Amante, L. et al. (2009). Evaluating Continuous Assessment Quality in Competence-Based Education Online: The Case of the e-Folio. European Journal of Open, Distance and E-Learning, No. 2. http://www.eurodl.org/?p=archives\&year=2009\&halfyear=2\&article=373

Petruzzellis, L., D’Uggento, A. M., \& Romanazzi, S. (2006). Student Satisfaction and Quality of Service in Italian Universities. Managing Service Quality: An International Journal, 16, 349-364. https://doi.org/10.1108/09604520610675694

Pollack, B. (2008). The Nature of the Service Quality and Satisfaction Relationship: Empirical Evidence for the Existence of Satisfiers and Dissatisfiers. Managing Service Quality: An International Journal, 18, 537-558.

http://www.ingentaconnect.com/content/mcb/108/2008/00000018/00000006/art00001 https://doi.org/10.1108/09604520810920059

Rajab, A., Rahman, H. A., \& Shaari, R. (2011). International Students' Perception towards the Education Quality. International Journal of Social Sciences and Humanity Studies, 3, 49-58.

Rezaei, M., Rezaei, H., Alipour, H., \& Salehi, S. (2011). Service Quality, Client Satisfaction and Client Personality in the Public Companies. Australian Journal of Basic and Applied Sciences, 5, 483-491.

http://www.academia.edu/download/45230235/Service_Quality_Client_Satisfaction_an d_20160430-19526-7jdilj.pdf

Rod, M., Ashill, N. J., Shao, J., \& Carruthers, J. (2009). An Examination of the Relation- 
ship between Service Quality Dimensions, Overall Internet Banking Service Quality and Customer Satisfaction: A New Zealand Study. Marketing Intelligence \& Planning, 27, 103-126. https://doi.org/10.1108/02634500910928344

Rózsa, Z. (2013). Assessment of Perceived Quality of SEMPA Educational Services. The 7th International Days of Statistics and Economics, Prague, 19-21 September 2013, 1221-1228. https://msed.vse.cz/files/2013/74-Rozsa-Zoltan-paper.pdf

Saadati, S. (2012). The Measurement Education Services Quality Payam Noor University of Garmsar with Using of Servqual Model. Journal of Basic and Applied Scientific Research, 2, 6337-6343.

Saunders, M. N. K., Lewis, P. \& Thornhill, A. (2009). Research Methods for Business Students (5th Edition). London: Pearson Education.

Senthilkumar, N., \& Arulraj, A. (2011). SQM-HEI-Determination of Service Quality Measurement of Higher Education in India. Journal of Modelling in Management, 6, 60-78. https://doi.org/10.1108/17465661111112502

Seymour, D. T. (1992). On Q: Causing Quality in Higher Education. Riverside, NJ: Macmillan Publishing Company. http://eric.ed.gov/?id=ED350951

Sultan, P., \& Wong, H. Y. (2012). Service Quality in a Higher Education Context: An Integrated Model. Asia Pacific Journal of Marketing and Logistics, 24, 755-784.

https://doi.org/10.1108/13555851211278196

Sumaedi, S., Bakti, I. G. M. Y., \& Metasari, N. (2011). The Effect of Students' Perceived Service Quality and Perceived Price on Student Satisfaction. Management Science and Engineering, 5, 88-97.

Sundaram, D. S., Mitra, K., \& Webster, C. (1998). Word-of-Mouth Communications: A Motivational Analysis. In J. W. Alba, \& J. W. Hutchinson (Eds.), NA-Advances in Consumer Research (Vol. 25, pp. 527-531). Provo, UT: Association for Consumer Research. http://acrwebsite.org/volumes/8208/volumes/v25/NA-25

Tabachnik, B., Fidell, L., \& Tabachnick B, F. L. (2007). Using Multivariate Statistics. NY: Harper Collins College Publishers (Internatio). London: Pearson Education.

Theodorakis, N., Kambitsis, C., \& Laios, A. (2001). Relationship between Measures of Service Quality and Satisfaction of Spectators in Professional Sports. Managing Service Quality: An International Journal, 11, 431-438. https://doi.org/10.1108/09604520110410638

Twaissi, N. M., \& Al-Kilani, M. H. (2015). The Impact of Perceived Service Quality on Students Intentions in Higher Education in a Jordanian Government University. International Business Research, 8, 81-92. https://doi.org/10.5539/ibr.v8n5p81

Umashankar, V., \& Dutta, K. (2007). Balanced Scorecards in Managing Higher Education Institutions: An Indian Perspective. International Journal of Educational Management, 21, 54-67. https://doi.org/10.1108/09513540710716821

van Schalkwyk, R. D., \& Steenkamp, R. J. (2014). The Exploration of Service Quality and Its Measurement for Private Higher Education Institutions. Southern African Business Review, 18, 83-107.

Walsh, G., Mitchell, V. W., Jackson, P. R., \& Beatty, S. E. (2009). Examining the Antecedents and Consequences of Corporate Reputation: A Customer Perspective. British Journal of Management, 20, 187-203. https://doi.org/10.1111/j.1467-8551.2007.00557.x

Wei, C. C., \& Ramalu, S. S. (2011). Students Satisfaction with University: Does Service Quality Matter? International Journal of Educational, 3, 1-15.

World Bank (2017). Lower Middle Income Countries. http://data.worldbank.org/income-level/lower-middle-income 
Yi, Y. (1991). A Critical Review of Consumer Satisfaction. In V. A. Zeithaml (Ed.), Review of Marketing 1990 (pp. 68-123). Chicago, IL: American Marketing Association.

Yunus, N. K., Ishak, S., \& Razak, A. Z. A. A. (2010). Motivation, Empowerment, Service Quality and Polytechnic Students' Level of Satisfaction in Malaysia. International Journal of Business and Social Science, 1, 120-128.

Zafiropoulos, C., \& Vrana, V. (2008). Service Quality Assessment in a Greek Higher Education Institute. Journal of Business Economics and Management, 9, 33-45.

http://www.tandfonline.com/doi/abs/10.3846/1611-1699.2008.9.33-45 https://doi.org/10.3846/1611-1699.2008.9.33-45

Zeithaml, V. A., Bitner, M. J., \& Gremler, D. D. (2006). Services Marketing: Integrating Customer Focus across the Firm. Boston, MA: McGraw-Hill/Irwin. http://library.wur.nl/WebQuery/clc/1809666

Zeithaml, V. A., Bitner, M. J., \& Gremler, D. D. (2009). Services Marketing: Integrating Customer Focus across the Firm (5th ed.). Singapore: McGraw-Hill and Irwin.

Zineldin, M. (2007). The Quality of Higher Education and Student Satisfaction SelfAssessment and Review Process a Term Philosophy and 5Qs Model. Paper presented at 2nd International Conference Education, Economics, and Law: Traditions and Innovations, Vaxjo University, Sweden.

Zineldin, M., Akdag, H., \& Vasicheva, V. (2011). Assessing Quality in Higher Education: New Criteria for Evaluating Students' Satisfaction. Quality in Higher Education, 17, 231-243. http://www.tandfonline.com/doi/abs/10.1080/13538322.2011.582796 https://doi.org/10.1080/13538322.2011.582796

\section{Submit or recommend next manuscript to SCIRP and we will provide best service for you:}

Accepting pre-submission inquiries through Email, Facebook, LinkedIn, Twitter, etc. A wide selection of journals (inclusive of 9 subjects, more than 200 journals)

Providing 24-hour high-quality service

User-friendly online submission system

Fair and swift peer-review system

Efficient typesetting and proofreading procedure

Display of the result of downloads and visits, as well as the number of cited articles

Maximum dissemination of your research work

Submit your manuscript at: http://papersubmission.scirp.org/

Or contact ce@scirp.org 